\title{
ポピュラーライブラリーエリア創出の可能性
}

地域公共図書館における開架フロアのゾーニング手法に関する研究

\section{A POSSIBILITY OF PLANNING A POPULAR LIBRARY AREA}

Studies of the method of zoning an open shelf floor at public libraries (1)

\author{
北岡 敏 郎* \\ Toshiro KITAOKA
}

\begin{abstract}
Both a multiple use and a family use of public libraries have increased recently. The former means that many adults use not only books but also magazines and AV materials, and the latter means that many children use libraries with their family. A series of studies shows that the method of zoning an open shelf floor with a popular library area is more reasonable and effective for those uses. In this method, an open shelf floor is divided into two zones in public libraries. One is an "active zone," which consists of a popular library area with a children's area ,a newspaper and magazines' area, and an AV materials' area. The other is a "quiet zone," which consists of other adults' book area with a reference area.

The results of this research are as follows : in most of general 7 public libraries,there is a principle that adults' books are arranged in order of the class and division of NDC. But the parts of <5.technology \& engineering $>$ books are not placed in the order and placed near a children's area or a newspaper and magazines' area. Many people use those books on technology and engineering more than other books. Therefore it can be said that some of those books is the core of a popular library.
\end{abstract}

Keywords: public library, open shelffloor, zoning, popular library, Nippon Decimal Classification, use 地域公共図書館、開架フロア、ゾーニング、ポピュラーライブラリー、NDC、利用

\section{1.はじめに}

著者は、これまで開架フロアのエリア配置構成 ${ }^{1)}$ について分析 し、近年の図書館利用の特徴である成人の複合利用とファミリ一利 用においては、一般書エリアと新聞・雑誌エリア及び児童書エリア の配置構成が影響することを指摘した。具体的には、成人の複合利 用では、一般書エリアと新聞・雑誌エリアの独立型よりも隣接型の 方が一般書と新聞・雑誌の複合利用が促進される2)。また、子ども が親と同伴するファミリ一利用では、一般書エリアと児童書エリア の切り離し型よりもエリア隣接型の方が子どもと親がそれぞれに主 目的利用をする分離利用が促進されることを明らかにした ${ }^{3)}$ 4)。つ まり、一般書エリアは、本来的に他のエリアから離れ静かに読書で きることが求められる一方で、逆に、これらのエリアと配置の関連 性が要求されることになる。

一方、近年、建設される地域公共図書館の蔵書数が増える中で、 特に一般書エリアの規模拡大が著しい。しかし、10万冊程度以上に 書籍が多くなると、これまでのように一般書エリアとしてひとまと めにするには無理があり、利用上も支障をきたす恐れがある5)。こ れを解決するためには一般書エリアの分割は避けて通れない。

先述の相反する二つのエリア配置要求を満たしつつ分割するため には、一般書エリアを他のエリアとの配置の関連性を重視するエリ アと、他のエリアから離れ静かに読書ができるエリアで構成するこ とが考えられる。そうすれば、前者は新聞・雑誌エリアや児童書エ

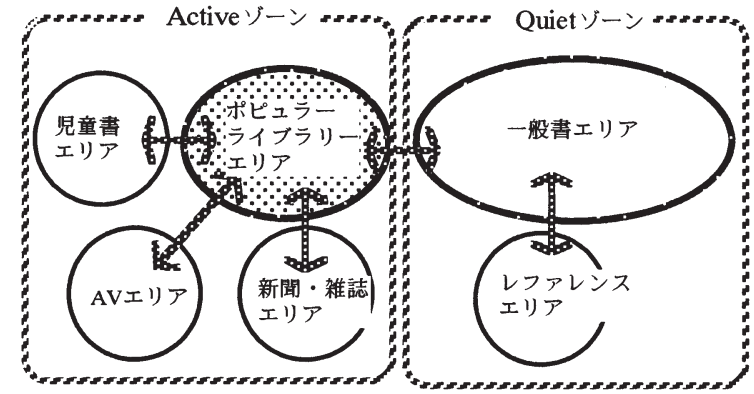

図 1 開架フロアの構成モデル

リアなどと隣接してゾーンを形成させ、後者はレファレンスエリア などと別のゾーンを形成させ得る。前者のゾーンはエリア間の活発 な利用が前提であるため、Activeゾーンとし、後者のゾーンは静か に読書や調查等を行うことが目的であるため、Quietゾーンとする （図 1)。いわゆる動と静によるゾーニングである。Active ゾーンに 配架される書籍は、利用者が多く、かつ、ファミリー利用で同伴す る親が利用しやすい書籍や、新聞・雑誌と複合利用されやすい書籍 でなければならない。本研究ではこれを「ポピュラーライブラ リ一」と呼び、これが配架された書架及びその周辺や付属した読書 スペースを含め「ポピュラーライブラリーエリア」と定義する。

これまで、ポピュラーライブラリーエリアについては軽読書コ一

\footnotetext{
* 有明工業高等専門学校建築学科 教授 ·博士 (人間環境学)

Prof., Dept. of Architecture, Ariake National College of Technology, Ph. D.
} 
表 1 調查対象図書館概要・調查概要

\begin{tabular}{|c|c|c|c|c|c|c|c|c|}
\hline 項目 & 図書館名 & $\begin{array}{l}F \text { 町立 } \\
\text { 図畫館 }\end{array}$ & M 図書館 & $\begin{array}{l}\mathrm{OM} \text { 市立 } \\
\text { 図書館 }\end{array}$ & $\begin{array}{l}\text { O市立 } \\
\text { 図書館 }\end{array}$ & $\begin{array}{l}\mathrm{Y} \text { 市立 } \\
\text { 図書館 }\end{array}$ & $\begin{array}{l}C \text { 市民 } \\
\text { 図書館 }\end{array}$ & $\begin{array}{l}\text { K町立 } \\
\text { 図書館 }\end{array}$ \\
\hline \multicolumn{2}{|c|}{ 資料年度（年） } & 1998 & 1997 & 1998 & 1999 & 1998 & 1998 & 1998 \\
\hline 蔵畫数（万冊） & 一般書＋児童書 & 約10.1 & 約16.3 & 約17.7 & 約17.8 & 約 22.0 & 約22.3 & 約 26.0 \\
\hline 開架冊数（万冊） & 一般書十児童書 & 約5.0 (8.9) & 約9.8(9.2) & 約12.5(15.4) & 約9.0 (10) & 約13.1 (不明) & 約11.3 (13) & 約9.3 (12) \\
\hline \multirow[t]{2}{*}{ 貸出制限 } & 畫籍 & $8(30)$ 冊/15日 & 10 冊/15日 & 10 冊/15日 & $5(10)$ 冊/15日 & 無制限/15 日 & 無制限/15日 & 10 冊/15日 \\
\hline & 雑誌 & 最新号以外 & 最新号以外 & 最新号以外 & 最新号以外 & 最新号以外 & 最新号以外 & 最新号以外 \\
\hline \multirow{3}{*}{$\begin{array}{r}\text { 図書館床面積 } \\
\left(\mathrm{m}^{2}\right)\end{array}$} & 延べ & 2,761 & 1,587 & 2,203 & 1,586 & 2,873 & 2,113 & 1,982 \\
\hline & 開架フロア & 815 & 936 & 1633 & 483 & 950 & 1078 & 1102 \\
\hline & 一般書エリア & 310 & 296 & 570 & 264 & 423 & 456 & 335 \\
\hline \multicolumn{2}{|c|}{ 市民1人当たり貸出冊数（冊/人） } & 11.1 & 8 & 4.1 & 7.9 & 9.5 & 8.3 & 17.3 \\
\hline \multirow[t]{2}{*}{ 調査年·月日 } & 第 1 回調査 & 93.09 .12 & 93.9 .26 & 94.05 .22 & 93.09 .19 & 95.11 .19 & 93.10 .24 & 93.11 .21 \\
\hline & 第 2 回調査 & 98.11 .8 & 97.11 .23 & 97.11 .16 & 98.11 .15 & 97.11 .30 & 97.11 .09 & 98.11 .01 \\
\hline
\end{tabular}

ナーとしてブラウジングェリアと混同して解釈・提案されてきたも のが多かったが6)、現在は一般的に「軽い資料を気軽に座ってくつ ろぎながら軽読書する」ところと認識・紹介されている7)。ところ が、そもそも資料に軽・重があるのかという議論や我が国の地域公 共図書館の蔵書は専門書が少ないので軽読書コーナ一をことさら設 ける必要性は少ないとする主張があるためか8、我が国ではあまり 採用されていないのが実状である9)。これらの是非はともかく、状 況を打開するためには、利用者要求に裏付けられた新たなポピュ ラーライブラリーエリアが求められる。

以上の認識を踏まえ、本研究は、新しくポピュラーライブラリー エリアを創出して地域公共図書館の開架フロアをゾーニング手法に より再構築することの妥当性と有効性を明らかにするものである。

対象とする図書館は、蔵書数 10 万冊前後から 30 万冊程度の中規 模館である。というのも、この規模程度が現在最も一般的になりつ つあること、従来（1970～80 年代）の 5 万冊程度の図書館では書 籍の貸出機能中心の平面計画が求められたが、この規模になると資 料の種類や数が多くなり、前述の如く利用は多様化し、加えて滞在 型化した利用にも対応した平面計画が求められるからである。

一方、対象外になるが、近年の大規模図書館の中にはポピュラー ライブラリーエリアが設けられているものが散見され10)、先述の如 く、蔵書規模が大きくなると一般書エリアを分割せざるを得ないこ との証左である。これらのポピュラーライブラリーは専門書部門あ るいはレファレンス部門に対応するものとして位置づけられたよう であるが、中にはポピュラーライブラリーの規模が 10 万冊を越え 中規模館に匹敵するものもあり、本論で定義したポピュラーライブ ラリーエリアとは質的に異なる。

研究の課題と方法：一般に我が国の書籍分類はNDC（日本十進 分類法）に基づいており、地域公共図書館においても例外ではな い。ところが、この分類は主題別と言いながらも学問分野別の分類 であり、大学図書館では有効であり得ても、こと地域公共図書館の 利用実態には合わないことがたびたび指摘されている。したがっ て、NDC 分類でどのように配架するかが問題である。特に、近年 の図書館利用の特徴である複合利用やファミリ一利用に対応させる ために、図書館側で何らかの配架の工夫がされていてもおかしくな い。そこで、本編は、既存図書館の書籍配架においてすでにポピュ ラーライブラリーエリア形成の萌芽がみてとれることを示し、さら に利用実態の分析とあわせて、どのような書籍に注目すべきかを㭘
討し、ポピュラーライブラリーエリア創出の可能性を追求する。第 二編では全国の図書館の配架実態を調べその位置が模索されている 状況を統計的に分析し、さらにポピュラーライブラリーとしてどの ような書籍が適当であるかを提案する。第三編は実際にActive ゾー ンを形成した図書館利用の分析から、提案するゾーニング手法の有 効性を検証する。

調査概要: 調查対象は、 $F$ 県内の、中規模で比較的貸出利用が多 いごく一般的な図書館を 7 館選定した ${ }^{11}$ （表 1)。調查は、2000 年 7月〜 10 月にかけて一般書エリアの書籍配架を調べ、配架方針を ヒヤリングし、NDC 分類毎に蔵書数・年間の貸出冊数を収集した 12)。また、開架書籍は貸出中が多いため、開架冊数のかわりに書棚 の長さを測定した ${ }^{13)}$ 。利用人数は、1993 年〜 1998 年の休日 2 日間 について開館から閉館まで30分毎に断面調查し、利用者の位置、姿 勢、行為等を平面図に記録したデータから一般書エリアの書籍を利

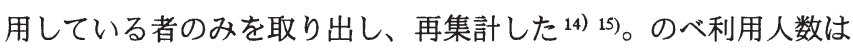
3325 人である ${ }^{16)}$ 。配架調查と利用者調查の時期に数年の開きがあ るが、この間、一般書エリアの書籍配架状況に大きな変化はなく、 分析に支障はないと判断した ${ }^{17)}$ 。また、10 年以上前の利用データ であり、現在は、コンピュー夕検索機器の普及により、求める書籍 が決まっている場合や逆に探しても見つからない場合にそれを利用 する者がやや増えてはいるが、依然として、多くの利用者は求める 書籍が決まっておらずブラウジングにより書籍を決めていることか ら、分析結果は現在でも有効であると判断した。

\section{2. 書棚長さの割合}

配架の仕方を分析する前に書棚長さの割合をみておく。書棚長さ を用いるのは開架冊数の把握が難しいこともあるが、計画論的には 利用人数と空間の規模を扱う上で有効な指標になり得ると考えるか らである。

NDCの分類は3 次区分までなされるが、まず、1次区分の類目は $<0$ 総記 $><1$ 哲学 $><2$ 歴史 $><3$ 社会科学 $><4$ 自然科学 $>$ $<5$ 技術 $><6$ 産業 $><7$ 芸術 $><8$ 言語 $><9$ 文学 $>$ の 10 区分 である。各類目の中は 2 次区分の綱目 $0 \sim 9$ の 10 区分、また、各 綱目の中は 3 次区分の要目 $0 \sim 9$ の 10 区分に分けられる。

このうち類目毎の書棚長さの割合をみると、その割合は各館とも 比較的共通している（図 2)。具体的には、<9 文学 > (文庫含む) は図書館により幅はあるものの約 $36 〜 44 \%$ と最も多く、次いでく 
3 社会科学 $>$ が約 13〜 16\%、<7 芸術>が約 9～13\%、<2 歴史

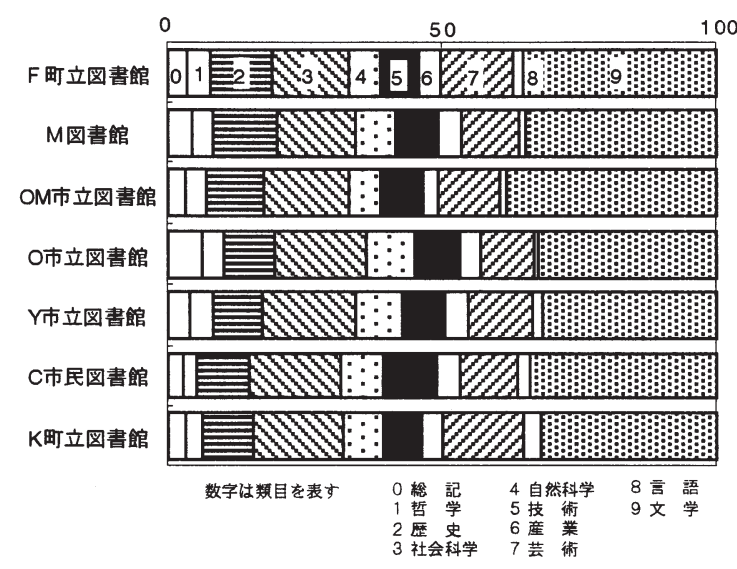

図 2 書棚長さ割合
$>$ が約 8〜 $12 \%$ 、 < 5 技術 $>$ は図書館による差が最も少なく約 7 $9 \%$ ある。< 0 総記 $><1$ 哲学 $><6$ 産業 $><8$ 言語 $>$ はどの館 も $6 \%$ 以下と少ない。この量的な側面の違いは次に述べる如く書籍 配架に影響を及ぼしてる。

3. 一般書の配架の仕方（図 3)

（1）共通した配架の特徵

一般書の配架の仕方は図書館により様々であるが、比較的共通に みられる配架の特徵は次の通りである。

(1)各館とも、NDCの類目毎にまとめその順に配架することを基本 としている。各類目は 1 つ書架の片側を最小単位として配架され ている場合が多く、類目の中は 2 次区分の綱目順、その中は要目順 に細分して並べる。この類目順に配架された典型例はOM館と K館

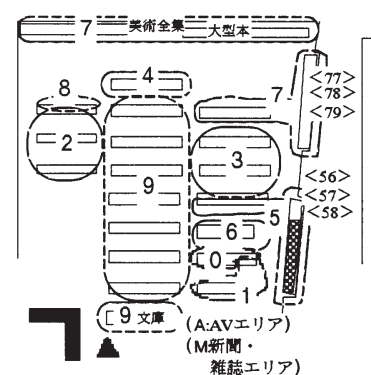

書籍配架 雑誌エリア

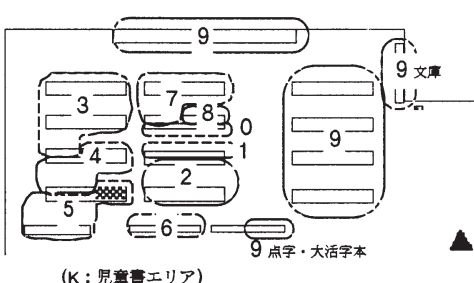

書籍配架
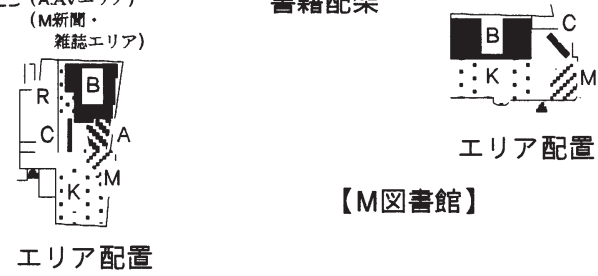

【M図書館】

エリア配置

\section{【F町立図書館】}

エリア配置 B：一般書エリア

凡例 $M:$ 新聞・雑誌エリア $A: A \vee エ リ ア$

$\mathrm{R}:$ レファレンスエリア

綱目を表す。

*2 四角枠は書架列のレイアウトを表す。

*3網脚け部分は網目 $<59>$ の配架位置を示す。

$\mathrm{K}$ : 児童書エリア

$C ：$ カウンター

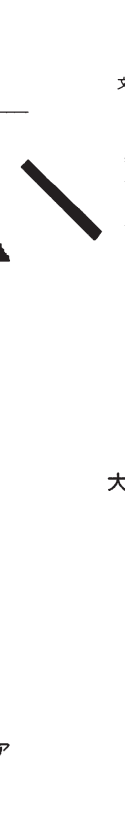

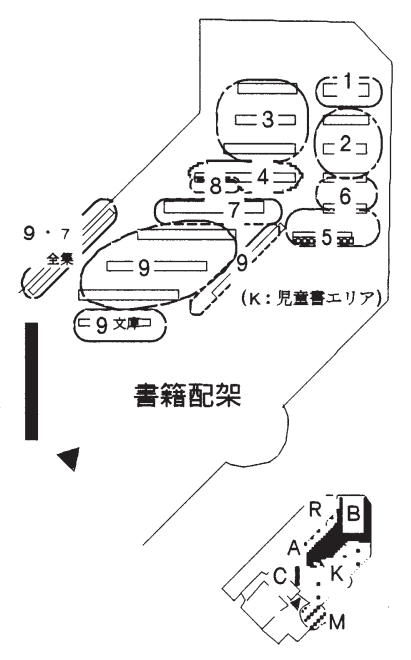

エリア配置

【○市立図書館】

【OM市立図書館】

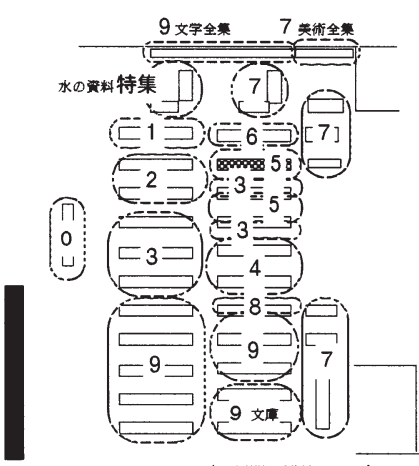

$\Delta$

書籍配架

【Y市立図書館】

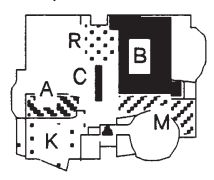

エリア配置

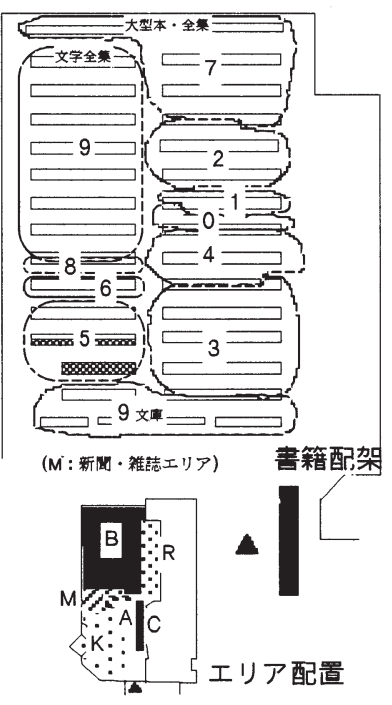

【C市民図書館】

図 3 一般書エリアの書籍配架

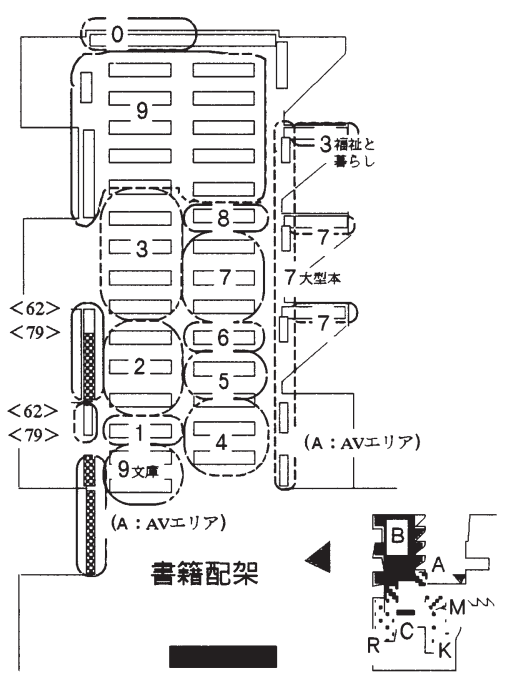

【K町立図書館】
エリア配置 
である。そこまではないが、M、O、C 館は隣り合う2〜3の類目 毎にまとめ、その中は類目順である。また、残りのF館とY館も部 分的に隣り合う類目をまとめている。理由は、NDC の分類順に配 架するのが最も書籍を管理しやすいからであり、NDC 順に配架す ることが共通の配架原則になっている。

(2) $<9$ 文学 $>$ は最も開架冊数が多く書架スペースを広く必要とする ため、その位置はカウンターからみて一番手前側か、逆に最も奥の 方に位置させる二通りがあり、前者が $5 / 7$ 館と多く、後者はC 館と $\mathrm{K}$ 館の2館である。K館の館長によれば、一般的には手前側におか れるケースが多いが、多くの利用者に建物内を広く利用してもらう ために意図的に奥側に配架したものであり、C館は後述するように $<3$ 社会科学 $><5$ 技術 $>$ を手前に配架した結果である。

(3) 逆に、 $<0$ 総記 $><1$ 哲学 $><6$ 産業 $><8$ 言語 $>$ は書架 1 列 程度以下であり少ないため、 $\mathrm{F}$ 館の 8 類、 $\mathrm{K}$ 館の 0 類のように他の 類目同士の関連を優先させて配架されやすい。

(4) $<3$ 社会科学 $><5$ 技術 $><7$ 芸術 $>$ の類目の配架位置及び方法 は後述するように図書館で異なる。

(5)全館とも形態から文庫本はまとめ ${ }^{18)} 、<9$ 文学 $>$ の位置に関係な くカウンターや新聞・雑誌エリア近くに位置させる。

(6)全館とも大型本や全集等の全部ないし一部は壁面や空下の書架を 利用する。そのため、これらを多く含む類目 $<7$ 芸術 $><9$ 文学 $>$ は書架列の端部など壁面や空下の書架が利用できる位置に置かれや すい。もちろん、大型本は各類目にあり、数がそれほど多くないた め類目毎に書架の最上段や最下段の棚にまとめるのが一般的である が、 $<7$ 芸術 >は写真集や美術全集等の大型本が特に多いためであ り、<9 文学 >は全集が多く、形態は大きくないが壁面に並べて一 望しやすくするためである。

（2）生活に密着した類目の配架の仕方

ここでは、生活に身近な資料が多いく 5 技術 $>199$ とそれに関連 した $<3$ 社会科学 $>20)<7$ 芸術 $>21)$ の配架位置に注目する。

(1) F 町立図書館 : カウンターからみて奥の列にNDC順を無視し て $<3$ 社会科学 $><5$ 技術 $><7$ 芸術 $>$ を集めて配置するが、その 位置は<7 芸術 $>$ の大型本の空下配架にあわせ最も奥側に配置され ている。ところが、そこはもう一方の壁面が利用できるため、<5 技術 $><7$ 芸術 $>$ は壁面の書架にも連続させ、類目の中の後半部分 の綱目 $<59$ 家政学・生活科学 $>$ (以下、 $<59>$ と略す) や $<78$ ス ポーツ・体育 $>・<79$ 諸芸・娛楽 $>$ 書籍が一望できるようになっ ている。館長によれば、く59>は主婦の利用を考え、新聞・雑誌 エリアに近づけるためのエ夫である。

(2)M図書館 : 類目 $0 \rightarrow 2 、 3 \rightarrow 6 、 7 \rightarrow 8$ は順にまとまっているが、 グループの配置は不規則である。その中で $<3$ 社会科学 $><4$ 自然 科学 $><5$ 技術 $>$ はカウンターからみて最も奥まった所にあるが、 特に<5 技術>はカウンターから見通しの良い位置で、児童書エリ アにも隣接して配架されている。特に、<59>は1䇢所にコンパ クトにまとめられ、児童書エリアへの見通しがよく、ファミリー利 用で行き来しやすい位置が選ばれている。

(3) OM 市立図書館 : 奥の配列は厳格にNDCの類目順であり、他 の図書館とは異なり類目毎に近くの空際にそれそれれ大型本を配架 している。類目順の並びの $<6$ 産業 $><7$ 芸術 $>$ の間がカウンター 正面の最も近い位置になるため、新聞・雑誌エリアの一部を挟んで
いる。そのため、<5 技術＞は新聞・雑誌エリアに隣接していない が、く6産業>の裏側で、それに近い位置におかれたものである。

(4) ○市立図書館 : NDC 順に数類目毎にまとめるが、グループ毎 の順番は崩して手前側に $<5$ 技術 $><6$ 産業 $>$ を配置し、特に $<5$ 技術 $>$ は児童書エリアに面している。この $<5$ 技術 $>$ は、 5 類内の 綱目順の並べ方を逆にして児童書エリア側にく59>を配架してお り、館長によれば、子ども連れの母親の利用を意識したものであ る。

(5) Y市立図書館 : 奥から NDC 順に $1 \rightarrow 3$ と並び、横に折り返し て $4 \rightarrow 6$ と配置するが、後者の列の $<5$ 技術 $>$ の書架間にわざわざ $<3$ 社会科学 $>$ の一部を挟み「技術と暮らし」のコーナーとしてい る。館長によれば、利用頻度が多く関連して利用される書籍を近づ けるためである。

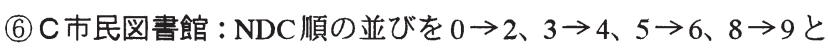
隣り合う類目毎にまとめた配架であるが、これらのグループの配架 順は不規則である。しかし、入口に最も近い方で新聞・雑誌エリア に隣接した位置にく文庫 $>$ ともに<3 社会科学 $>$ と $<5$ 技術 $>$ が くるように配置し、資料相互の関連性を重視するとともに、特にく 5 技術 $>$ は、O 館と同様に類目内の綱目順の並べ方を逆にして、く $59>$ を最も新聞・雑誌エリア近くに配架している。

(7) K町立図書館 : 文庫本を除くとカウンターからみて奥の方へ 1 $\rightarrow 3 、 4 \rightarrow 8$ の 2 列配置であり、 $<5$ 技術 $><7$ 芸術 $>$ もこの中に 含まれている。しかし、この書架列とは別に空下や壁面の書棚にく 5 技術 $><6$ 産業 $><7$ 芸術 $>$ の一部を綱目・要目で取り出し混成 させた「暮らしの本棚」コーナー ${ }^{22)}$ があり、<59>の全部と<79 諸芸・娛楽 $><62$ 園芸 $>$ の部から成る。館長によれば、主婦が 利用しやすいようにまとめたものである。また、それとは反対側の 位置に<3 社会科学 $>$ の部（主に<36 社会 $>$ ) を取り出し、高 歯者など「暮らしと福祉の特集」コーナー23)を設けている。7館の 中では唯一、類目単位ではなく綱目・要目単位に取り出したもので ある。

以上より、1）<5 技術＞は、NDC順の配架を遵守した OM 館を 除く残り全ての図書館で、NDCの類目順を崩しても児童書エリア や新聞・雑誌エリアに近づけるないしは隣接させたり、あるいは他 類目との資料相互の関連性を考えるといった配架の工夫がみられ る。<3 社会科学 >はK $\mathrm{K}$ 館のように一部の資料で独自にコーナーを 形成している場合もあるが、むしろ、Y、C、F館のように<5 技術 $>$ との資料相互の関連性からの配架が多い。<7芸術>は、前述の 大型本の壁面配架要求を満たしつつ、可能であればF館やOM館の ように<5 技術 $>$ の隣りや新聞・雑誌エリアに面させている。つま り、配架の工夫の中心は $<5$ 技術 $>$ と考えてよい。

2）<5 技術>の中で、配架の土夫の主対象は<59>であり、主婦 や子ども連れの母親あるいは女性の利用者を意識して、5類内の綱 目順の並びを変えてでも児童書エリア $(\mathrm{O} 、 \mathrm{M}$ 館) や新聞・雑誌エ リア（C、F館）に近づけたり、隣接させている。ちなみに、く 59 >は (家庭経済)、(家庭理工学)、(衣服)、(裁縫)、(手芸)、(理容・ 美容)、(食品・料理)、(住居・家具調度)、(家庭衛生)、(育児) と いった家庭生活に密着した要目からなり、<5技術 $>$ の中で最も多 く、調查対象図書館では書棚長さで約 $34 \sim 55 \%$ を占める。

3）調查対象図書館の多くは、NDCの類目毎のまとまりを崩さない 
ことを前提にく 5 技術 $>$ の類目全部の配架位置を工夫しているが、 一方で、 K 館のように 5 類の配架とは別にく $59>$ だけを取り出し 関連する他類目の一部とまとめる方法がみられ、ポピュラーライブ ラリーエリアを創出する際の参考になろう。

\section{4. 利用状況}

2次区分の綱目毎の利用は把握が困難なので、ここでは類目を単 位とした利用の状況を利用人数と年間貸出冊数で分析する。利用人 数は一般書エリア内の書架周辺で書籍を選択あるいは立ち読みして いる人数であり、30 分毎断面の 2 日間合計人数である。

(1) 利用人数

類目毎の利用人数割合は各館ともある程度共通しており (図 4)、 最も多い<9 文学 $>$ が約 $28 \sim 41 \%$ 、次いで $<5$ 技術 >が約 $12 \sim 18$ $\%$ 、 $<7$ 芸術 $>$ が約 8〜20\%、逆に利用者が少ないのはやはり $<0$ 総記 $><1$ 哲学 $><6$ 産業 $><8$ 言語 $>$ であ、ほとんどが $5 \%$ 以 下である。このことだけみれば、おおまかには書棚長さの割合と同 様の傾向を示し、書棚長さに比例した利用人数と考えられるが、そ

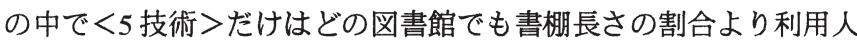
数割合の方がかなり多い。つまり、<5 技術>は配架スペースは少 なくて利用は多いことを示している。そこで利用効率をみるため

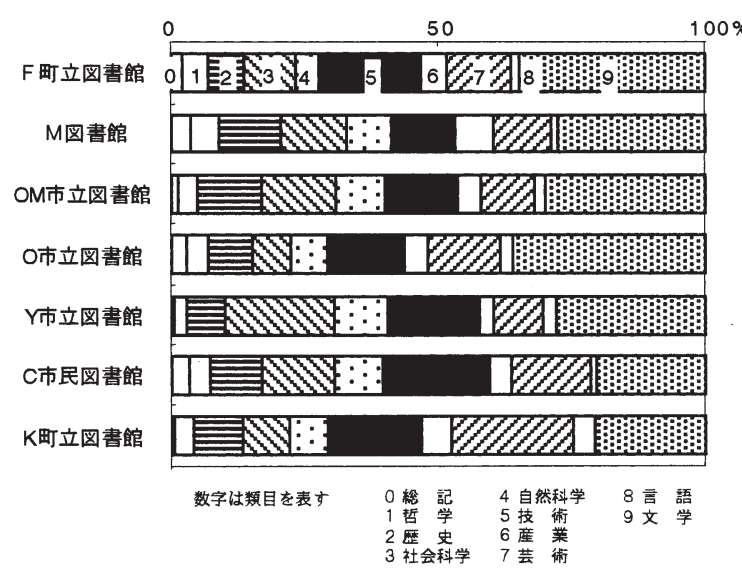

図 4 利用人数割合

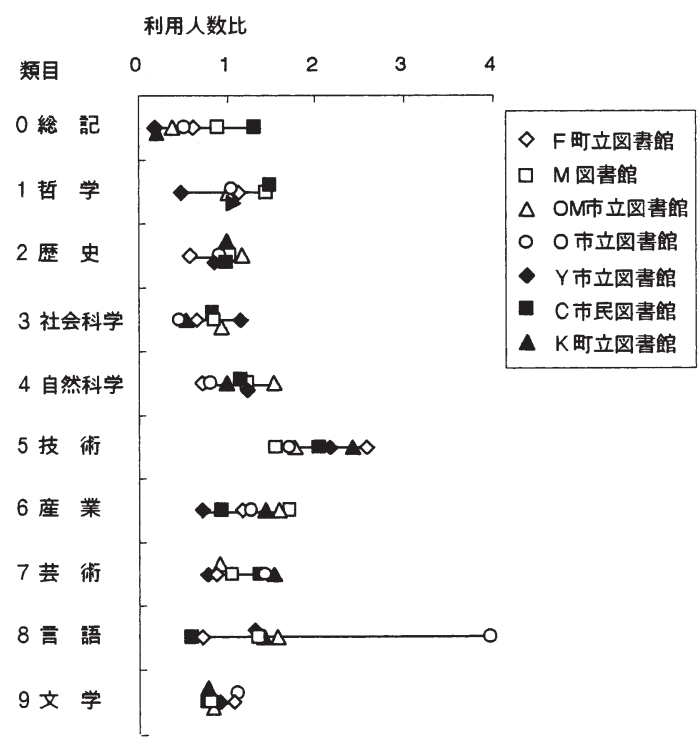

図 5 利用人数比
に、利用人数割合と書棚長さの割合の比、つまり、書棚の単位長 さ当たりの利用人数比 (類目毎の単位長さあたり利用人数/全体の 単位長さ当たり利用人数、以下、利用人数比）を考える。利用人 数比をみると（図 5)、書棚長さの割合が小さい類目 $<0 、 1 、 6 、 8$ $>$ は值がやや大きくなる傾向は認められるものの、O館の $<8$ 言語 $>$ を除き ${ }^{24)}$ 、< 5 技術 $>$ 以外の類目は 1.4 以下で、その大半は 1.0 前後以下、すなわち、書棚長さに応じた利用人数かそれ以下が多

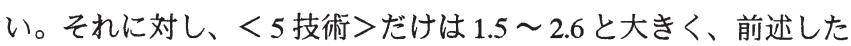
利用効率の高さを裏付けている。その中で、K館とF館では2.4、2.6 と他の図書館の $1.5 \sim 2.1$ より特に大きく、空下や壁面に配架され た効果でもあろうが、NDC順の配列から取り出され分かりやすい からといえる。このことは、利用人数の側面だけからみれば、一 般書の配列から取り出すことでは同じであるポピュラーライブラ リーエリア創出の有効性を示唆していると考えられる。と同時に、 <5技術 $>$ の類目のまとまりを崩さずに配架の工夫をするよりも、 綱目く59>を取り出す方が利用効率は高くなり得ることを示して いる。

\section{（2）貸出冊数}

OM市立図書館は貸出冊数統計がなされていなかったため、それ を除く6館で分析する。貸出冊数割合も利用人数と同様の傾向を示

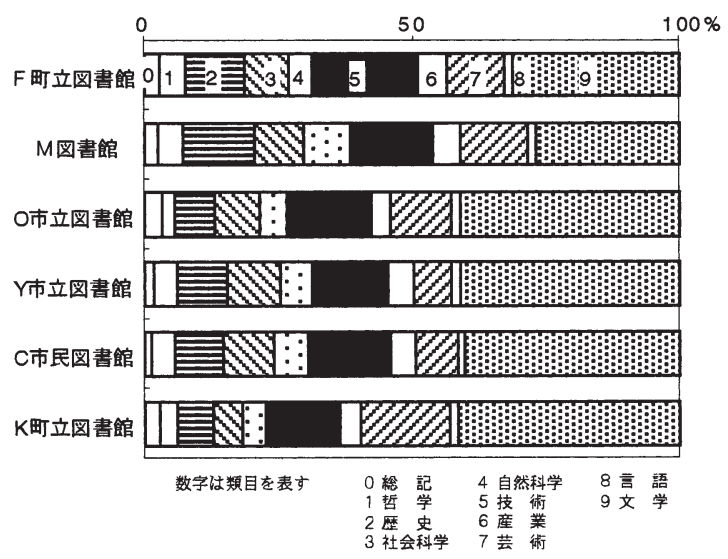

図 6 貸出冊数割合

貸出冊数比

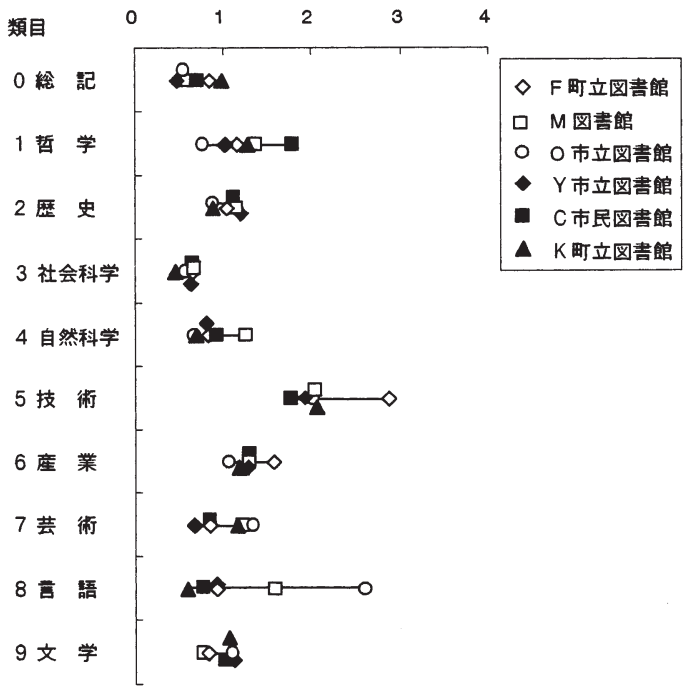

図 7 貸出冊数比 
し、最も多いのが $<9$ 文学 $>$ の約 $27 \sim 42 \%{ }^{25)}$ 、次いで $<5$ 技術 $>$ 約 $14 \sim 20 \%$ 、< 7 芸術 $>$ 約 7〜 17\%である（図 6)。<9 文学 $>$ は 別格として ${ }^{26)}$ 、やはり、 $<5$ 技術 $><7$ 芸術 $>$ の貸出利用はどの図 書館でも多い。貸出効率をみるために先程同様、貸出冊数割合と書 棚長さの割合の比、つまり、書棚の単位長さ当たりの貸出冊数比 (類目毎の単位長さあたり貸出冊数/全体の単位長さ当たり貸出冊 数、以下、貸出冊数比) をみると (図 7)、O館の $<8$ 言語 $>$ を除き、 $<5$ 技術 $>$ はやはりどの図書館とも他の類目より值は大きく、貸出 効率が最も高い類目である（唯一、C館の<1哲学 $>$ のが同程度 である)。その中ではく $59>$ 全部を壁面に配架した F 館が 2.9 と最 も大きいが、K館は2.1と他館の1.7〜2.0 とそれほど変わらず、NDC 順の配列から<59>を取り出し別置する方法に利用人数ほどの優 位性はみられないが、さりとて他館より低い值になっているわけで はない。

\section{5. まとめ}

ごく一般的な地域公共図書館の書籍配架の実態とその利用を分析 し、開架フロアにActiveゾーンを設ける際に核となるポピュラーラ イブラリーエリア創出の可能性について検討した。以下、要約す る。

1）一般書エリアにおいて共通的にみられる配架の特徵は、基本 的に書籍をNDCの類目毎にまとめ、できるだけ類目順に配架する ことである。それができない場合でも、隣り合う数類目毎にまとめ て配架する。これは全館に共通して認識されている配架方針であ り、配架原則と考えてよかろう。その上で、<9文学 $>、<7$ 芸術 $>$ 、<文庫 $>$ などは開架冊数の多さや本の形態及び利用上から、入 り口近くや壁面・空下書架を利用しやすい位置に配架されやすい。

2）生活に身近な資料が多い $<3$ 社会科学 $><5$ 技術 $><7$ 芸術 $>$ において、図書館の配架の工夫は $<5$ 技術 $>$ が中心であり、NDC の類目順の配架を崩しても、新聞・雑誌エリアゃ児童書エリアとの 関連で配置されているケースが多い。また、 $<3$ 社会科学 $><7$ 芸 術 >は条件が許す場合に資料相互の関連性から $<$. 技術 $>$ 近くに 配架する傾向が窥われる。

3) 特に<5技術 >の中でも、配架の工夫の主対象は<59家政学・ 生活科学>であり、5類内の綱目順の並びを変えてでも児童書エリ アや新聞・雑誌エリアとの配置の関連性が図られている。ごく一 般的な地域公共図書館において、<5 技術 $>$ とわけく59家政学・ 生活科学>にこのような配架の工夫が窅え、新聞・雑誌エリアや児 童書エリアとのつながりが考えられ、実際の利用においても<5技 術>は利用効率、貸出効率ともに大きいことから、これらの土夫は 提案するポピュラーライブラリーエリア創出の萌芽とみてよかろ う。また、ポピュラーライブラリー構成の検討に際しては、<59 家政学・生活科学>に注目する必要がある。

4）<59 家政学・生活科学 >を<5. 技術 >の類目内にとどめる よりも、類目の配架とは別に取り出す方が利用効率は高い。このこ とは、利用人数の側面から、NDC 順の配架列から取り出し独立さ せることでは同じであるポピュラーライブラリーエリア創出の有効 性を示唆している。

今回はごく一般的な地域公共図書館を対象にしたものであり、全 国的にどのように配架の工夫がなされているかの解明が課題であ
る。尚、本研究は平成 $13 \sim 15$ 年度文部科学省科学研究費補助金 (基 盤研究 C (2)) による。

注

1)これまでコーナーと称していたが、空間用語としてはいささか不適切であり、 欧米で用いられている用語に統一した。

2)北岡敏郎ほか:成人の複合利用からみた公共図書館のコーナー構成とブラウジ ングについて 日本建築学会計画系論文集 第 486 号 pp.61 68 1996.8

3)北岡敏郎ほか:図書館利用型の構成とその特徵 ファミリー利用からみた公共 図書館のコーナー構成に関する研究 (1) 日本建築学会計画系論文集 第498 号 pp.117 122 1997.8

4)北岡敏郎ほか: : 分離>利用型の特徵と児童書コーナーと一般書コーナーの配 置構成 ファミリー利用からみた公共図書館のコーナー構成に関する研究 (2) 日本建築学会計画系論文集第 518 号 pp.129 135 1999.4

5) 実際、テーマによってはNDCの複数類目にまたがっており、規模が大きくな ると書架間の行き来が大変で、混乱している利用者、特に高齢者がよくみうけ られる。

6)北岡敏郎ほか:我が国の公共図書館におけるブラウジングコーナーの概念とそ の変遷について 日本建築学会計画系論文集 第509号 pp.113 119 1998.7

7）例えば、上松貞夫・木野修造 : 図書館シリーズ 9 図書館建筑 - 施設と設備樹書房 pp.114 1986

8）本田明ほか：図書館貝選書 15 図書館施設を見直す 日本図書館協会 1986 9）ポヒュラーライブラリーを設けた図書館は 1990 年代前半まで 3 例ほどしか知 り得なかった（前揭6）参照）。

10）例えば、神戸市立中央図書館、青森市民図書館、市川市中央図書館、横浜 市中央図書館などがある。

11)ごく普通の図書館においてさえどのように配架の工夫がありうるか、つまり、 質的特徵を捉えるためである。したがって、その量的側面は次編にゆずる。

12) 蔵書数は 1998 年度 (但し、Y市立図書館のみ 1997 年度)、年間の貸出冊数は 1999 年度の資料を用いた。

13）開架書籍は貸出中のものが多くあるため、開架冊数は捉え難い。仮に 1 日の 平均貸出冊数が 1000 冊とすれば、貸出期間 15 日で 15000 冊、児童書やAV資 料、雑誌の数を除いても 10000 冊程度が常時貸し出されていることになる。

14）利用者調査は、デー夕数を增やし経年的信頼性を確保するため、時期を 2 回 に分け調査したものである。

15）利用人数の算定では、書架を見ながら本を選んだり、立ち読みしている者の みを数え、スツール等に腰掛けて読書している者はどの書架の本か不明のため、 たた通過している者や会話している者とともに除いた。類目への振り分けは、 書架間の中心で行った。中心付近で判断できない場合は、両類目に 0.5 人ずつ 振り分けた。

16）内訳は、F町立図書館 312 人、M図書館 539 人、OM市立図書館 685 人、O市 立図書館 391 人、Y市立図書館 357 人、C 市民図書館 692 人、K町立図書館 349 人である。

17) 1999 年の書籍配架予備調查の時点までは大きな変化はなかったが、2000年に 書棚長さを測定した際に、2館で配架位置が一部変更されていた。図書館貝に 以前の配架位置と類目毎の書棚量が以前とほとんど変わらないことを確認した 上で、変更後の書棚長さを測定した。

18)小説以外の文庫本は該当する類目に分けて配架する場合が多い。したがって、 ここで言う文庫本は小説である。

19） $<5$ 技術 $>$ は正しくは< 5 技術・工学・工業>であり、網目は $<50$ 技術・工 学 $>$ に始まり、<51 建設工学・土木工学 $><52$ 建築 $><53$ 機械 $>\cdots<58$ 製造業 $>$ と続き、最後は $<59$ 家政学・生活科学 $>$ ある。

$20 ）<3$ 社会科学 $>$ は $<36$ 社会 $><38$ 風俗習慣・民俗学 $>$ に日常生活に身近な 資料が多い。

21）<7芸術 $>$ の網目は $<70$ 芸術 $>$ に始まり、 $<71$ 彫刻 $><72$ 絵画・書道 $>\cdots$

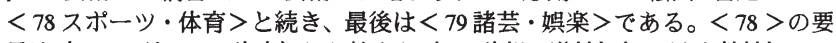
目は（780スポーツ・体育）から始まり（781体操・遊技）（782 陸上競技）… (786戸外レクレーション) …(789武道) と屋外を中心としたあら蚛るス゚ー

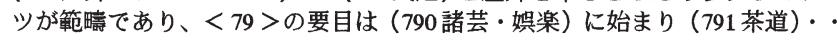
(793 花道) ․ (795 囲碁) (796 将棋) ․ (798 室内嬠楽) (799 ダンス) とむし ろ室内を中心とした日常生活の趣味や㜥楽的な範疇のものからなる。

22)「暮らしの本棚」コーナーには $<49$ 医学 $><38$ 冠婚・葬祭 $><14$ 占い $>も$ 数こそ少ないが含まれている。

23）暮らしと福祉の特集コーナーは、(364社会保障)（365生活・消費者）(367家 族・男女・老人問題) (369社会福祉) (378 障害児教育) の資料で構成されてい る。

24）<8言語）について言えば、O館の利用人数は 9 人、貸出冊数は 2277 冊であ り、他館が $4 \sim 14$ 人、 1465 冊〜 5405 冊であることから必ずしも突出した利用 というわけではない。しかし、書棚長さは $5220 \mathrm{~mm}$ と他館の $1 / 2.3 \sim 1 / 6.7$ とき わめて短いために、利用人数比、貸出冊数比が異常に高くなったものである。 25） M図書館の<9 文学>は低いが特に文庫本が少ないことが影響している。

26）－9文学>について言えば、最奥部に配架された T館と K館では利用人数割 合がやや低かったにも関わらず貸出冊数割合は他の図書館とかわらず、この限 りでは手前側か奥側かの位置にそうこだわる必要はなさそうである。 